\title{
Two versions of 'New Gourna' and the dilemma of sustainability in new urban communities in Egypt
}

\author{
K. G. Ahmed $^{1}$ \& L. Elgizawi ${ }^{2}$ \\ ${ }^{I}$ Arch. Eng. Dept., Faculty of Engineering, UAE University, Al Ain, UAE \\ ${ }^{2}$ Arch. Eng. Dept., Faculty of Engineering, Mansoura University, Egypt
}

\begin{abstract}
Gourna, a vernacular village in Upper Egypt was built above the Pharonic heritage site. In order to protect the monuments from theft, the Egyptian government commissioned Hassan Fathy in the 1940s to design a new settlement for the Gourna residents. Unfortunately, the project failed as most of the residents refused to move to the new village. Recently the government repeated the attempt, but this time the second version of the New Gourna was significantly different from Fathy's one. The main objective of this paper is to investigate if the second version of New Gourna is going to overcome the problems associated with Fathy's New Gourna and deals successfully with the sustainable vernacular architecture of the region. It has been found that both of the two 'New Gourna' projects reveal how the top-down official processes might end up with either a superficial mimicry to the authentic sustainable vernacular architecture or an imposed alien built environment.
\end{abstract}

Keywords: Gourna, vernacular architecture, urban communities, sustainability.

\section{Introduction}

Gourna, a small village in Upper Egypt near Luxor, was built by its residents about $100 \mathrm{~m}$ to the east of the Temple of Seti I. Old Gourna was a thriving community of five hamlets built along the hills in West Luxor, on the ancient cemetery of Thebes. Until the early 19th century the community included at least parts of the Temple of Seti I. Edward William Lane related in 1825 that the village was abandoned and not a single inhabitant lived there. Isabella Frances 
Romer suggests that the resettling started in the late 1840s [1]. It is claimed that the Gournii for generations had made their livelihood by tunneling into the tombs, plundering the contents and selling the artifacts on the black market. They built their houses in front of the tunnels to accord a certain degree of security to their operations [2]. Determined to stop the tomb robbing, the Department of Antiquities engaged Fathy in 1946 to design and construct a new village for the relocation of the Gournii. Recently, and after the failure of Fathy's project, the government repeated the attempt to move the residents. The main objective of the research is to investigate if the second version of New Gourna is going to overcome the problems associated with Fathy's New Gourna and if it is going to deal successfully with the vernacular architecture of the region or not. In order to undertake this investigation, the paper first reviewed the vernacular architecture of Gourna and then discussed both Fathy's approach and the recent New Gourna Village's approach.

\section{Background about the vernacular architecture of Gourna}

Much of Gourna was originally built on the hillside with mud bricks and wood. The height of houses ranged from one to two stories. The houses were built next to each other following irregular urban patterns that reflected the decisions made by the residents. These decisions were influenced by the community traditions and values. Also, the built environment was a mixed-use one where shops and workshops could be found on some of the ground floors of the houses, especially in those which abut main streets (fig. 1).

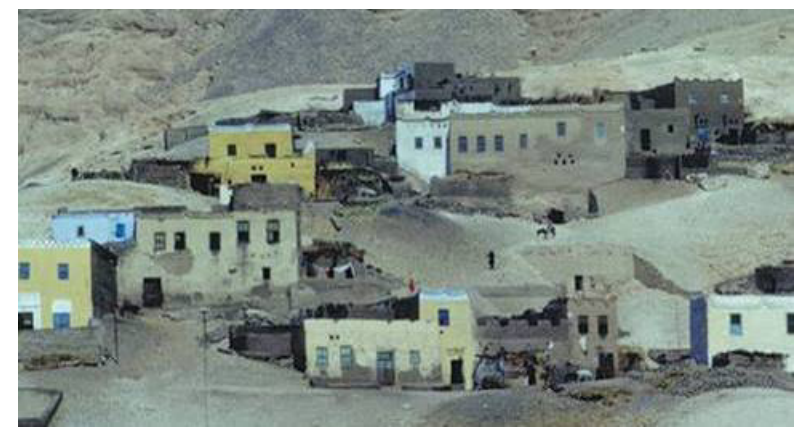

Figure 1: The urban form of the old Gourna, near the Valley of the Kings [4].

Residents used to utilize open spaces in front of their houses in different social and economic activities such as sitting areas for housewives, play areas for children, cooking and other domestic uses. Also, they used to raise poultry and other farm animals that they could afford to feed in these open spaces (fig.2). This resulted in demarcation and appropriation of the open areas in the outer spaces juxtaposed to the house front and thus shaped livable and vivid urban 

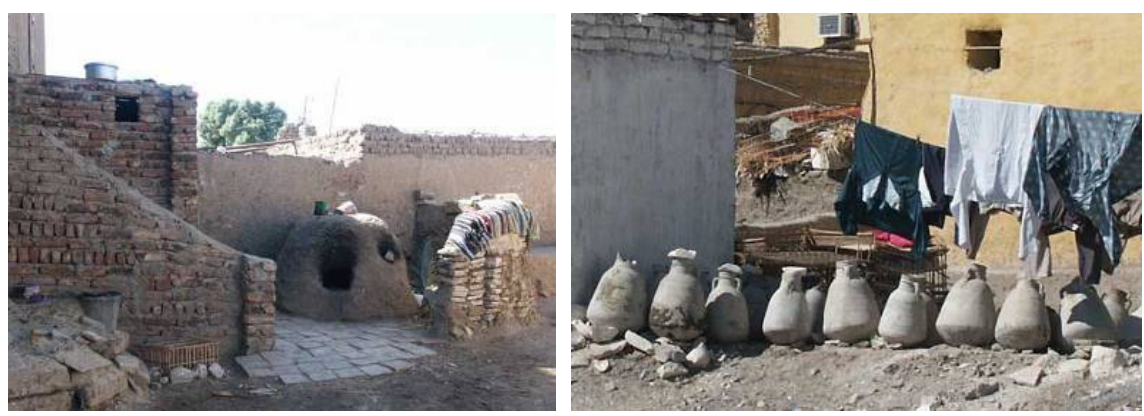

Figure 2: $\quad$ Demarcation and appropriation of open spaces [5].
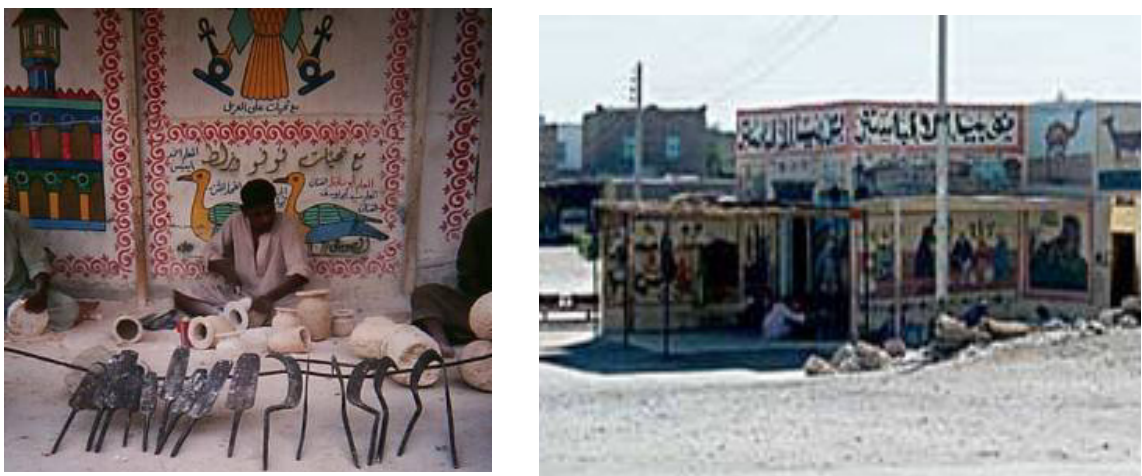

Figure 3: $\quad$ Working in carving alabaster $[5,6]$.

spaces within the residential context. Many of the people in Gourna were working in carving various objects from slabs of alabaster to sell to the tourists visiting the surrounding monuments [2].

The people of Gourna used to ornament the facades of their houses in a way that reflected their significant occasions such as performing pilgrimage (fig.4(c)) or to attract attention for their shops, which were usually occupying the ground floors of their homes (fig.4(a) and (b)). Residents actually paid attention to the facades of their houses, especially to the formation of the entrances and the skylines (fig.5). Some motives can easily be identified as they constitute a common convention among Gournii regarding the formation of the architecture mass. Colors also played a key role in having this sense of diversity within unity in the urban fabric of old Gourna.

\section{First version of New Gourna: Hassan Fathy's Gourna}

New Gourna village designed by the Egyptian architect Hassan Fathy was partially built between 1945 and 1948, lying roughly midway between the Colossi of Memnon and el-Gezira on the Nile. The main road to the Theban 
Necropolis runs right though it [1]. Fathy attempted to make the people of Gourna live in a harmonious social structure, free from abject poverty, disease and illiteracy, devoted to the pursuit of folk art, and framed by an appropriate and relevant architectural setting. In order to realize these goals Fathy planned the housing in irregular allotments (fig.6). In his view, these allotments would force variation in house plans while shaping a network of angular streets that turn on themselves to create broken vistas. Much of the lives of households are played out in these small, quiet streets that serve as extensions to the home, as workplaces and as play areas for children. The smallest unit in the hierarchy of open space is the multi-purpose courtyard incorporated into each house (fig.7).

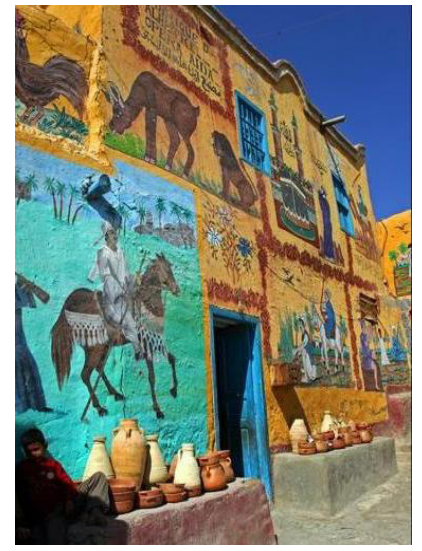

(a)

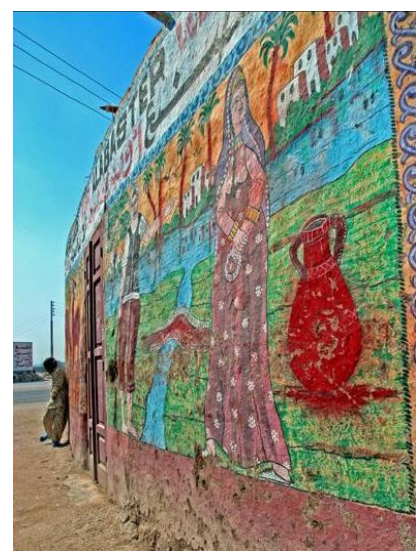

(b)

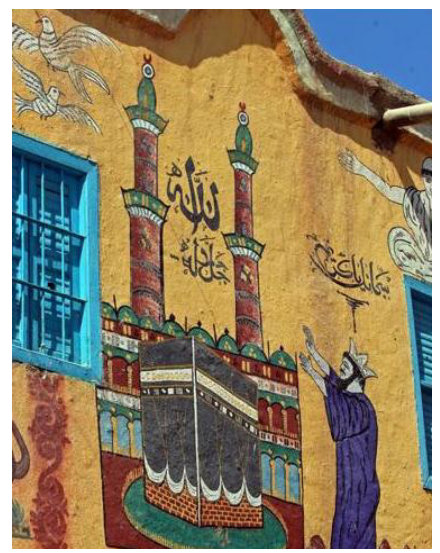

(c)

Figure 4: Vernacular ornaments on the exterior walls of houses [7]. 

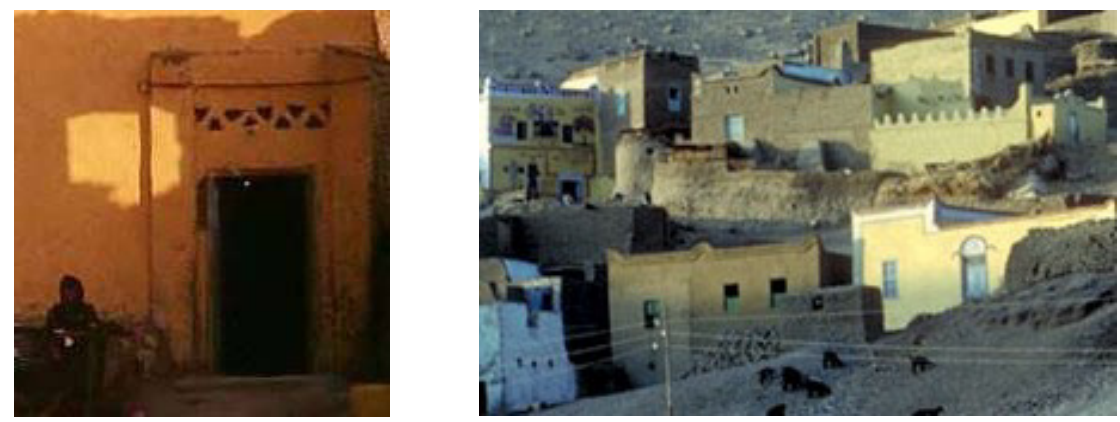

Figure 5: Examples of vernacular architectural elements in Gourna houses [7].

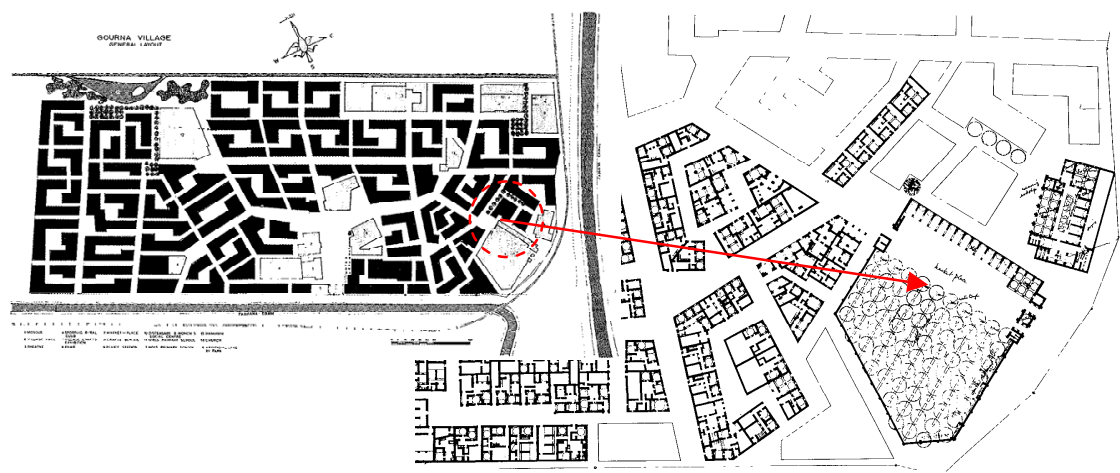

Figure 6: $\quad$ New Gourna Master Plan 1948 and Master Plan Implementation [2].

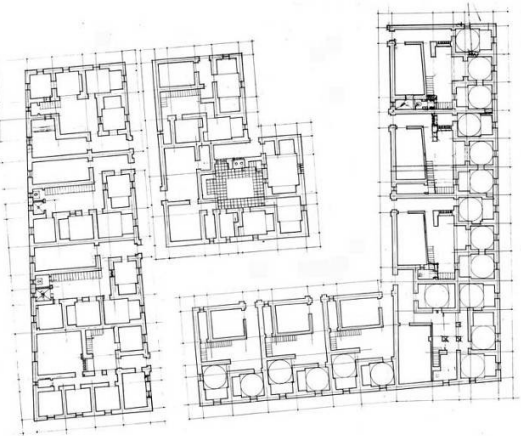

Figure 7: $\quad$ Housing pattern in Neighborhood 4 [4].

The village design began with this spatial unit. A man is led through an ascending scale of space that begins with the privacy of its small courtyard, leading to the semi-public neighborhood street, to the larger avenue, then the village square and finally the open fields of the Nile Valley. On the other hand, 
the main route to the village interior widens to create a kind of public square around which many of the community functions were to take place including prayer, shopping and entertainment, housed by the mosque, khan and theatre respectively. Informal socializing occurs in the streets or under the Byzantine domes that cover the village water wells (there is no running water in individual houses) (fig.8) [2]. Rather than subscribing to the current conventional idea of using a limited number of unit types, Fathy took the unprecedented approach of seeking to satisfy the individual needs of each family in the design. As he said in Architecture for the Poor [10], "In Nature, no two men are alike. The architecture of the house emerges from the dream; this is why in villages built by their inhabitants we will find no two houses identical. This variety grew naturally as men designed and built their many thousands of dwellings through the millennia." Fathy [10] argues that "the architect can consider the family size, the wealth, the social status, the profession, the climate, and at last, the hopes and aspirations of those he shall house. As he cannot hold a thousand individuals in his mind at one time, let him begin with the comprehensible, with a handful of people or a natural group of families which will bring the design within his power." However, even with this noble goal, Steele [11] raises the extremely important question of how to create a culturally and environmentally valid architecture that is sensitive to ethnic and regional traditions without allowing subjective values and images to intervene in the design process. Additionally, the flexibility of the house to accommodate its residents' changing needs and the applicability of incremental development remain questionable issues in Fathy's design.

Unfortunately, despite Fathy's sincere effort to design the New Gourna in an environmentally and socially-responsive manner, the residents of Gourna refused to move to their new village. Now most of the project has turned into ruins (figs.9 and 10). Originally planned for a population of 900 families, the completed project has a current population of approximately 130 families and covers one fifth of the original site. The Gournii, content with their living situation, resented the project and therefore were reluctant to cooperate. The final result was a partial realization of the master plan [2].

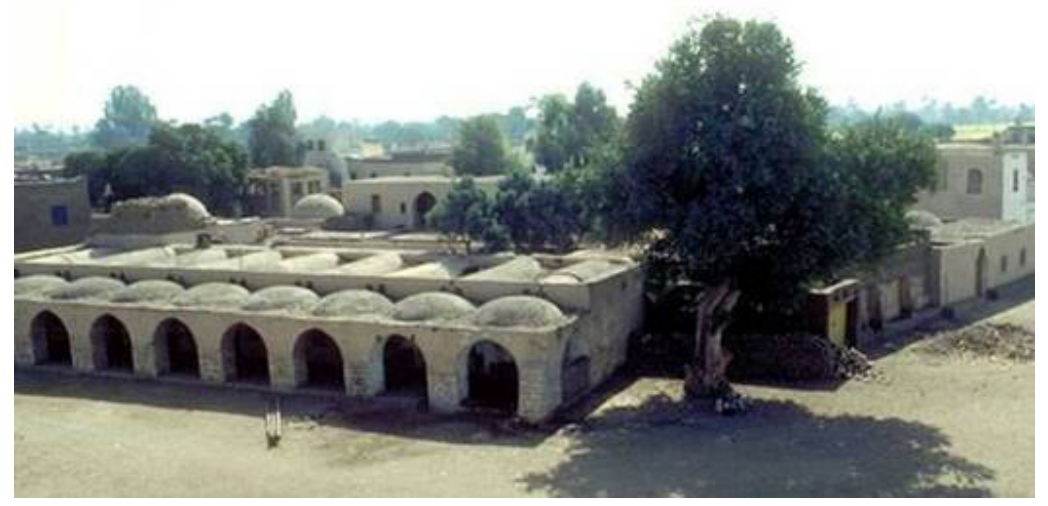

Figure 8: View to the village [4]. 


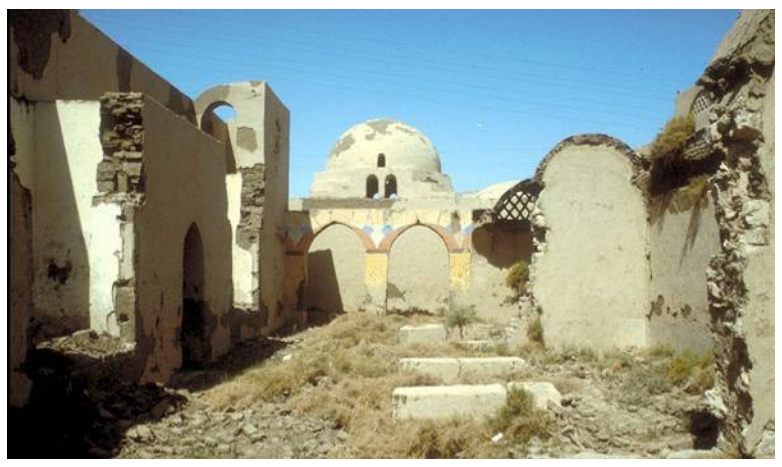

Figure 9: The New Gourna village turned into ruins [4].

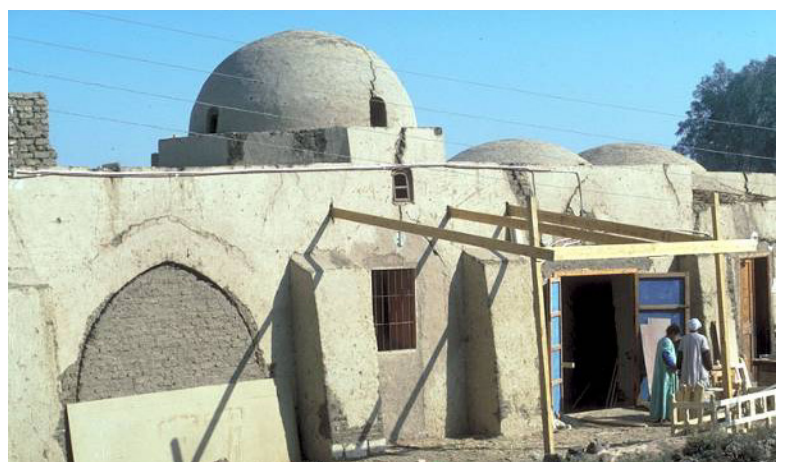

Figure 10: Adaptation of the original buildings of the village [4].

All that remains today of the original New Gourna is the mosque, market and a couple of houses. Most other houses in the village today are of newer origin [1]. In the end, many of the social services, such as the dispenser and women's social center, and the hammam (public bath), were neither provided nor facilitated, nor was all the proposed housing constructed. Several of the community buildings - the crafts exhibition hall, village hall and the khan (market) - though built, have never supported their intended functions and are now used as housing or workshop space [2].

\section{Second version of New Gourna}

Many decades after its first attempt to move the residents from old Gourna, the government repeated the attempt on the same background of protecting monuments. The second version of New Gourna, called Al Taref at the outset, was significantly different from that of Fathy. The work in this new village began in 1997 and was finished in 2006. Transferring residents to their new homes began on the 15th of August 2006. In order to force the residents to move, the government demolished most of the houses in old Gourna and left only a few houses to be re-used later as museums for the vernacular architecture of Gourna. 
The new village, which cost about 100 million Egyptian Pounds, has been planned to accommodate the 20,000 residents of the seven regions (Nogoa) of old Gourna who were living in about 4,000 housing units. New Gourna contains more than 2,000 houses, which were given to the moving residents for free. Additionally, about 1,500 plots have been distributed to some better-off residents for free in order to enable them to build four-story walk-up residential blocks by themselves according to a unified design model sharing the same architectural style. Services such as two schools, a police station, a youth center, a mosque, a health center and bakeries (figs.11 and 13) were also built [12]. The layout followed the criteria of the design of conventional residential districts where mixed-use has been avoided with most of the services accumulating in one central area. The central market (fig.13) seems to be driven from Fathy's Gourna; superficial items such as the concrete vaults and domes only meant to give a specific appearance rather than to achieve a functional goal. The area of the typical house model equals about $175 \mathrm{~m}^{2}$ and consists of one floor only. The houses are all identical in design and have two bedrooms, a seating area, a reception, a kitchen and a bathroom. Outside there is a small yard at the back and at the front a porch way and little mastaba in front of the main bedroom which has a door leading outside (fig.12).

The criticism for New Gourna is pivoted around many issues. Firstly, it is located some kilometers away from old Gourna and from any tourist sites. Residents who used to work in the alabaster factories could not afford the service car, so they walked there, a distance of approximately 3 kilometers. It has been claimed that residents have not been fairly compensated. Whereas in the past they were offered big houses and more space, right now no matter how big their old house was or how many family members they have they are offered only a one-story, two bedroom house that looks like a makeshift sea side chalet. The houses are very regimented and box like. In an interview with one of the villagers he pointed out that it is not a question of compensation, but of the fact that this is his home, this is the place where his great grandparents have lived and nobody has the right to force him out [8]. The allocation of the new houses had followed rules that residents could not understand. On the other hand, it is

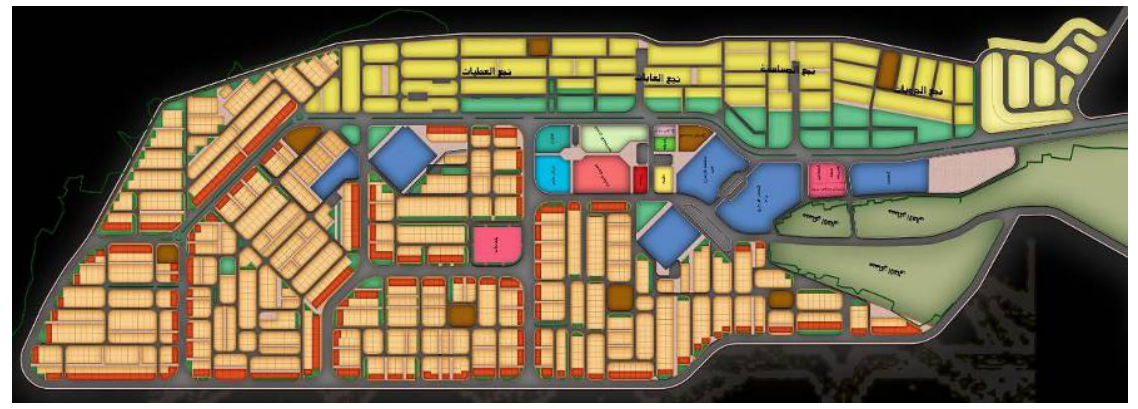

Figure 11: Al Taref, the layout of the village [13]. 


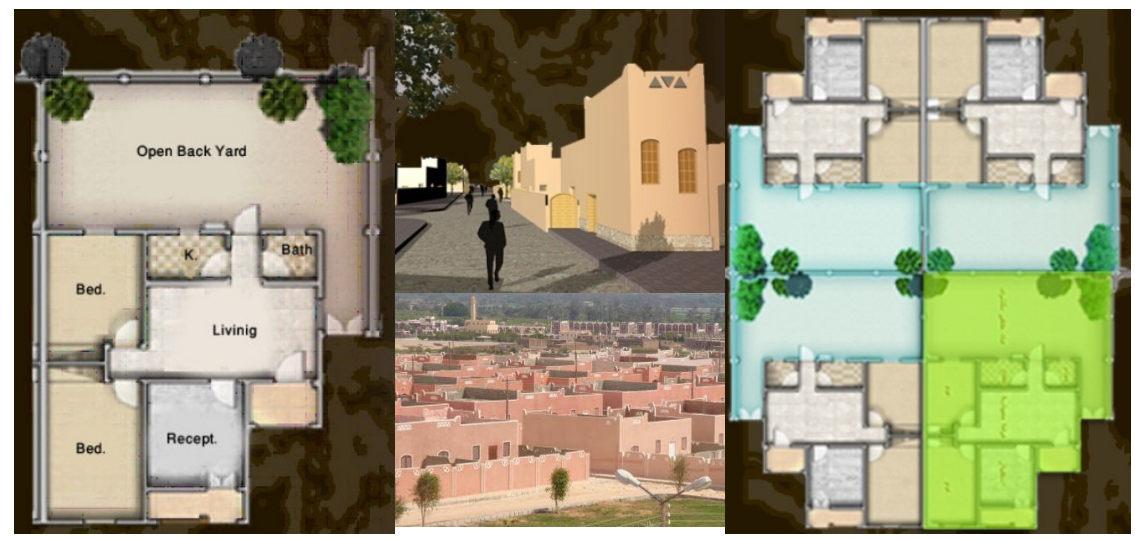

Figure 12: Al Taref, the houses [13].

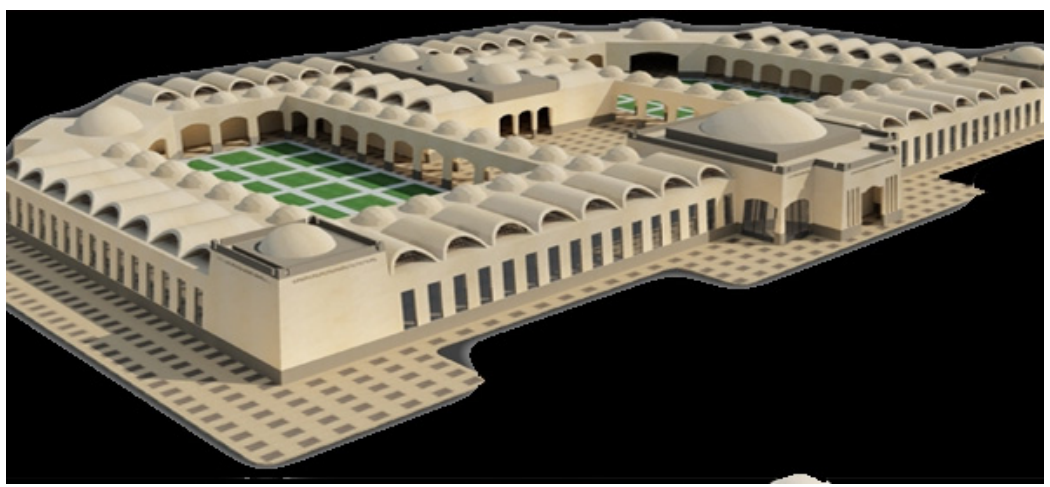

Figure 13: Al Taref, the market pseudo-Fathy's design [13].

obvious that everything is going to have to come from outside. For instance, the landscaping is supplied with water by truck. Also, everything has been provided by the government including the furniture. Residents said they had even been promised electrical equipment, such as washing machines, TVs and fans, which they have not yet received. People were concerned that after the Egyptian president's visit, all the contents would be taken away [9].

\section{The two versions of New Gourna and the crises of sustainable vernacular architecture}

In contrast to Fathy's Gourna, the new Gourna has been designed and built totally away from the local residents, who had no chance to participate in any process. Fathy argued in his book 'Architecture for the Poor' that when the architect is faced with the job of designing a thousand houses at one time, rather than dream for the thousand whom he must shelter, he designs one house and 
puts three zeros to its right, denying creativity to himself and humanity to man. As if he were a portraitist with a thousand commissions and painted only one picture and made nine hundred and ninety nine photocopies. This describes well the situation in the second version of new Gourna. Only one housing model is repeated with no consideration for individual needs and preferences that once shaped the old Gourna, which the government are demolishing but leaving at the same time a couple of houses from it to be used as a museum for the vernacular architecture of Gournii. People have not only been alienated from the design process, but also they cannot adapt or change anything in their houses as long as this might compromise the appearance of facades. Even with this officeprepared prototype design, many of the architectural motives of the vernacular architecture of Gourna, especially those of the entrances and skyline (fig.5), have not been incorporated. The pseudo-design of Fathy's Gourna in the design of the central market makes the situation even worse. In Fathy's design the vaults and domes came as appropriate techniques that people can build by themselves using local materials. However, in New Gourna the vaults and domes are merely meant for superficial appearance and are built using alien building materials and techniques imported to the region from far away locations. In addition, professionals actually leave no room for people to share in the construction process.

Although the designers are claiming that they took the residents' needs into consideration they actually ended up with a total destruction of the process that produced the vernacular architecture of Gourna. Thus, it might be claimed here that both of the two attempts to build a New Gourna reveal how the top-down official processes might end up with a superficial mimic to the authentic vernacular architecture or even impose a totally different built environment on it. Even with Fathy's dream to take individual needs into consideration, the research argues that the two cases share to some extent the negligence of the native residents, who are the main expert of vernacular architecture, and impose the architects' viewpoints on them. All the assets historically embedded in the Gourna vernacular architecture have been compromised and the vision of professionals and politicians eventually dominated the whole decision making process. As a result of this attitude, people who used to historically produce their own living environment have become extremely dependant on the government to do everything for them. Thus, it is expected that the project is going to end up a failure, as did its predecessor.

\section{Conclusions}

The research argues that the second version of New Gourna, as well as the first version of it with some major differences, has demolished the sustainable vernacular architecture of the region as it leaves no room for people to act. This shed light on the fact that no real appropriate vision has been realized so far in dealing with the dichotomy of development on one hand and sustaining the vernacular architecture on the other hand. Based on that, the research draws attention to the urgent need for an alternative approach when dealing with the 
regions that have vernacular architecture in order to sustain their social, cultural, economic and environmental essence and not to sustain their architectural characteristics in a superficial and cosmetic manner. This proposed approach should leave real room for people's actions and interactions without imposing office-prepared solutions on them. Instead, professionals and officials should give assistance to people to help them find solutions for their own problems, including the appropriate way to develop themselves in a way that matches the era of our time and in the mean time to preserve their values and traditions, which would help them sustain their vernacular architecture.

\section{References}

[1] Wikipedia, Kurna. Available online: [http://en.wikipedia.org/wiki/Kurna], first accessed on 13/09/2007.

[2] Richards, J.M., Serageldin, I. \& Rastorfer D., Hassan Fathy, Concept Media; Architectural Press Pte Ltd.: London, 1985.

[3] Shunya, Gourna, Available online: [http://www.shunya.net].

[4] Archnet, Gourna, Available online: [http://www.Archnet.net].

[5] Stephens, R. D., People of Gourna, Available online: [http://egypt.adventure.freeservers.com/photo15.html].

[6] Kohl, E., Gourna, Available online [http://www.our-trips.com].

[7] Egyptos, Le village de Gourna, Available online: [http://www.egyptos.net/egyptos/photos/Tombes-Tombeaux--Vallee-desnobles--Village-de-Gourna], first accessed on 17/09/2007.

[8] Arabist, Gourna: Where the Dead Come First. Available online: [http://arabist.net/hatshepsut/?p=24], first accessed on 11/09/2007.

[9] Akshar, J., New Gourna. Available online: [http://touregypt.net/ teblog/luxornews/?p=357].

[10] Fathy, H., Architecture for the Poor: An Experiment in Rural Egypt, University Of Chicago Press: Chicago, 2000.

[11] Steele, J., The Hassan Fathy Collection. A Catalogue of Visual Documents at the Aga Khan Award for Architecture, The Aga Khan Trust for Culture: Bern, Switzerland, 1989.

[12] Ibrahim, A. \& Ghitah, H., The New Taref Village in Luxor: A practical Exam for the Desert Village, Al Ahram, 17 August, P.28, 2006.

[13] Supreme Council for Luxor, Al Taref, Official report, Supreme Council for Luxor: Luxor, 2006. 